\title{
Prehistoric Lithic Procurement Sites: A Vanishing Resource
}

Don R. Dickson

Historic Preservation Associates

Follow this and additional works at: https://scholarworks.sfasu.edu/ita

Part of the American Material Culture Commons, Archaeological Anthropology Commons, Environmental Studies Commons, Other American Studies Commons, Other Arts and Humanities Commons, Other History of Art, Architecture, and Archaeology Commons, and the United States History Commons

Tell us how this article helped you.

This Article is brought to you for free and open access by the Center for Regional Heritage Research at SFA ScholarWorks. It has been accepted for inclusion in Index of Texas Archaeology: Open Access Gray Literature from the Lone Star State by an authorized editor of SFA ScholarWorks. For more information, please contact cdsscholarworks@sfasu.edu. 


\section{Prehistoric Lithic Procurement Sites: A Vanishing Resource}

Creative Commons License

(c) (i) (8)

This work is licensed under a Creative Commons Attribution-NonCommercial 4.0 International License 


\title{
PREHISTORIC LITHIC PROCUREMENT SITES: A VANISHING RESOURCE
}

\author{
Don R. Dickson, \\ Historic Preservation Associates
}

This paper is a synthesis of data presented at the 1994 Caddo Conference. Based on the response to this paper during and after the conference, it would seem that many archeologists are unaware of the severity of the problem being considered: the rapidity with which lithic resources are vanishing.

Lithic procurement sites may be divided into three broad categories:

\section{1) LITHIC RESOURCE PROCUREMENT} ZONES. This type of location may be a strean gravel bar or a hillside talus slope where lithic raw materials were obtained from the surface. Stream gravel deposits and talus slopes were probably the most common sources of knappable raw materials if one may judge from the primary decortication flakes recovered from most archeological sites.

2) LITHIC EXTRACTIVE AREAS. This site category represents bedrock or bluff exposures where raw materials were simply broken from the available outcrop without quarrying into it. Weathering processes often have obscured the evidence of such activities. However, some debitage, produced by testing of chert or reduction into blanks or preforms, can usually be seen on the surface, and occasionally hammerstones or aborted preforms can be found at these sites.

3) QUARRIES. At these important sites, dig ging or quarrying intruded into solid bedrock or into strata of unconsolidated bedrock or clay to obtain the desired raw materials. Examples of such sites include the well known Peoria Quarry in Ottawa County, Oklahoma, the less familiar Golden Grove Quarry in Barton County, Missouri, and the Indian Mountain Quarry at Hot Springs National Park in Arkansas. Abundant debitage, many aborted preforms and hammerstones can be found at such locations.

Unfortunately, many archeologists are unaware of the rapidity with which these lithic procurement sites are being destroyed. Since many of them are located in areas not usually associated with prehistoric sites, such as on elevated ridges or in mountain settings often far from water, they are not monitored regularly by archeologists and often eliminated or damaged without scientific notice of such damage. For example, when I visited the Peoria Quarry in 1992 to obtain samples of the raw material, I discovered that over 90 percent of the site had been destroyed by leveling the ground for several houses. Later, in 1993, additional damage was done to the site by the installation of a water line through the remaining part of the site. In August, 1994, I visited the Golden Grove Quarry in Barton County, Missouri only to find that the owner of the site had recently filled in all of the one to two meter deep pits so that he could plant the area in fescue. In the Ouachita area near Hot Springs, hundreds of prehistoric quarries have been destroyed already by novaculite mining operations to obtain material for silica products and whetstones. The huge aboriginal quarrying complex on Spanish Mountain near Magnet 
Volume 5, Number 3

Cove, Arkansas has been damaged severely, although portions of it are still intact.

Another, often unrecognized threat to quarries and extractive'areas is the widespread prevalence of avocational and commercial knapping enterprises. Texas, Missouri, and many other states have large groups of individuals who replicate prehistoric bifaces, especially such popular types as Folsom, Clovis, Dalton, and Scottsbluff points. Of course, there is big money in such activities because well made replications currently bring between $\$ 5$ and $\$ 10$ per inch, or more in the case of especially well made fluted points. As one night guess, many of these modern replications are being sold as "ancient artifacts" after proper treatment to make them seem old. Several people who knap full time are able to obtain new four-wheel-drive vehicles each year and live in extremely nice homes. Of course, such knappers are quite interested in obtaining as much high grade chert as possible ....... and guess where they get it? To be more specific, at one time the Carr Branch area in Ottawa County, Oklahoma yielded tons of extremely high grade chert nodules (probably Reeds Spring in origin). One knapper found out about this location, took in a truck and literally hauled away all available chert to use and sell. Ten years ago one could obtain large quantities of high quality Woodford chert nodules south of McAlester along the lndian Nations Turnpike. Today, one cannot procure even a fragment of this chert along the turnpike. In fact, it is very difficult to find Woodford chert anywhere in the area. At a recent knap-in held east of Kansas City, Missouri, I was informed that one participant had available over a ton of Mill Creek chert from the famous Mill Creek Quarry area. In spite of the fact that this is not a high quality or fine textured chert, and was used mainly in prehistoric times in the manufacture of hoes, this knapper still had obtained a large amount of it. A recent visit to the southern Illinois area indicated that almost all of the high quality Kaolin and Cobden chert has been obtained by knappers.

Perhaps the most dramatic, almost unbelievable, instance of chert procurement was told to me recently by a knapper himself. This person was in the Edwards Plateau area of Texas picking up a few hundred pounds of chert when two 18-wheelers from Pennsylvania pulled up at this location and crews started gathering all available chert. They had an order for two full loads of Texas chert!

Archeologists today need to consider two important factors. First of all, if one is going to obtain representative chert samples to use in the future for comparative purposes, this obtaining must be done NOW. In fact, it is almost too late to get samples of some cherts already. Second, if we are going to define the extractive strategies employed by prehistoric knappers at important quarry sites, we are going to have to work quickly. Limited studies in southern Kansas suggest that antler wedges and hammerstones were used to extract chert from Threemile Limestone deposits at 14PO57 (Banks 1990:Fig.5.13). However, extractive strategies employed in Missouri, Oklahoma, Arkansas, and elsewhere are essentially unknown. Considering the significance of lithic procurement in the lives of prehistoric peoples, we should act now to obtain what information is still available. Even now it may be impossible to obtain a proper perspective on prehistoric lithic resource availability in certain areas.

\section{REFERENCE CITED}

Banks, Larry D.

1990 From Mountain Peaks to Alligator Stomachs: A Review of Lithic Sources in the Trans-
Mississippi South, the Southern Plains, and Adjacent Southwest. Oklahoma Anthropological Society Memoir 4. 